Suggested citation: Zdybel D. (2020). Children's conceptions of knowledge and cognition: On the development of epistemic thinking in early and middle childhood, "Elementary Education in Theory and Practice," vol. 15, no. 3(57), pp. 145-163. DOl: 10.35765/eetp.2020.1557.10

\title{
Children's Conceptions of Knowledge and Cognition: On the Development of Epistemic Thinking in Early and Middle Childhood
}

\author{
Dziecięce koncepcje wiedzy i poznania - o rozwoju \\ myślenia epistemologicznego dzieci we wczesnym \\ i średnim dzieciństwie
}

\section{KEYWORDS}

metacognition, epistemic thinking, conceptions of knowledge and learning, culture of thinking, elementary education

\section{ABSTRACT}

Metacognitive and epistemological reflection are often perceived as being beyond the perceptive and cognitive abilities of young children. Research, however, has proven that at a very early stage of development children are naturally intrigued by their own minds, observe and draw conclusions, build personal conceptions of knowledge and cognition, and quickly move from the stage of "naïve theories of mind" to reflecting on more advanced epistemological phenomena. The aim of this article is present the idea of epistemological reflection and its role in the development of children's conceptions of knowledge and cognition. Theoretical considerations will be complemented with a research project driven by the following research questions: What is the conception of knowledge among young children? What differences do they perceive between knowledge and learning? Visual and verbal explanations prepared by children will be used to present the role such personal epistemology plays in future self-regulation competency and in constructing children's ability to evaluate their own learning and set new aims. In summary, the conclusions for educational practice will be discussed. 


\section{SŁOWA KLUCZE ABSTRAKT}

metapoznanie, Refleksja metapoznawcza i epistemologiczna są często uważane za refleksja formy aktywności niedostępne percepcji małego dziecka. Tymczasem

epistemologiczna, badania świadczą, że dzieci już na stosunkowo wczesnych etapach rozkoncepcje wiedzy i uczenia się, kultura woju są żywotnie zainteresowane tym, co dzieje się w umyśle człowieka, obserwują i wyciągają wnioski, formułują własne, osobiste teorie myślenia, edukacja wczesnoszkolna wiedzy i uczenia się, szybko przechodząc od tzw. „naiwnych teorii umysłu” do rozważań natury epistemologicznej. Celem niniejszego artykułu jest przybliżenie czytelnikom istoty refleksji epistemologicznej i roli, jaką odgrywa ona w rozwoju dziecięcych koncepcji wiedzy i poznania. Analizy teoretyczne wzbogacone zostaną prezentacją projektu badawczego, który zmierzał do znalezienia odpowiedzi na następujące pytania: Jaką koncepcją wiedzy posługują się dzieci w młodszym wieku szkolnym? Jakie dostrzegają różnice między wiedzą a uczeniem się? Na podstawie analizy semantycznej zebranych wypowiedzi graficznych i werbalnych dzieci ukazana zostanie rola osobistej epistemologii jako istotnego wymiaru przyszłej kompetencji w świadomym regulowaniu własnego uczenia się, ocenianiu jego skuteczności i wyznaczaniu sobie kolejnych celów. W podsumowaniu tekstu przedstawione zostaną wnioski dla praktyki edukacyjnej.

\section{Introduction}

What sets apart a good school from a bad one in the modern world is the importance it attaches to shaping the cognitive independence of a child: their ability to learn independently and to take responsibility for the results of their work. As the experts of the EU Council stress, in the contemporary, knowledge-based economy, the mere memorization of facts, concepts, dates, and procedures—although extremely important - is not enough to ensure the wellbeing, progress, and success of both the individual and the community. According to Hoskins and Fredrikson, in our rapidly changing society, skills such as problem-solving, critical thinking, the ability to cooperate, creative thinking, numeracy, and self-regulation are more essential than ever. These are tools that allow what has been learned to be put into practice in real time in order to generate new ideas, theories, products, and knowledge (Hoskins, Fredrikson 2018: C189/1). From this perspective, the key dimensions of learning, which form the basis of self-regulation, are as follows (Hoskins, Fredrikson, 2008: 28-30):

metacognitive reflection, defined as "thinking about thinking," that is, the ability to consciously monitor and regulate the course of knowledge acquisition, to perceive and correct one's errors in thinking, to critically evaluate the results of cognitive processes, and to consciously plan future activities (Flavell 1979; Kanevsky, Geake 2004) 
- epistemic thinking, i.e., understanding the essence and structure of knowledge, and realizing the criteria of its validity and credibility (Kuhn 2000; Hofer 2004).

The main goal of the article is to focus the reader's attention on the epistemological framework, which is least present in the education of a young child. The first part of this article presents a short overview of the most important psycho-pedagogical research on the development of childhood concepts of knowledge and cognition, as well as the discrepancies in the definitions. The second part presents a research project on children's understanding of the essence of knowledge. Based on pupils' visual and verbal expressions, I demonstrate the potential of a child's epistemic thinking at an earlier school age, which may be supported or obstructed by the epistemological atmosphere created in the classroom by the teacher.

\section{Epistemological Thinking: Definitions}

The epistemic thinking of young children is rarely the subject of pedagogical considerations. Although much research on the development of epistemological thought has been carried out since the 1970s, most researchers have focused on adolescence and early adulthood, which are considered to be a time of drastic, crucial developmental changes (King, Kitchener 2004). Interestingly, the term epistemic thinking/ epistemological knowledge does not have a single, universally accepted definition. Researchers disagree about the course (mechanism) of epistemological thought and the forms under which it manifests in the human mind (cf. Bendixen, Feuch 2010; Bendixen, Rule 2004; Briell et al. 2011; Hofer, Bendixen 2012). To what extent is epistemological knowledge metacognitive? Does it depend on the discipline, or is it rather general and cross-disciplinary? What representations do the fruits of epistemological thinking have in the human mind: is it an internally coherent and orderly system of beliefs, activated in a problematic situation, or rather the processes of reasoning/reflection and underlying assumptions/pre-concepts, or perhaps even more primary, not fully conscious forms of understanding? Is this knowledge organized and ordered like a theory, or does it appear in a form similar to that of common knowledge, i.e., naïve, unstable, often self-contradictory, and susceptible to changes under the influence of current experiences (Kuhn, Weinstock 2002)? The disagreement among researchers as to the essence and structure of personal epistemology result not only in differences in research methodology, but also in terminological chaos. In a metaanalysis of over 600 scientific publications, Briell et al. (2011: 8-11) distinguished as many as 39 different terms used to describe people's beliefs about knowledge. Some of the most commonly used concepts are summarized below, mainly to make readers aware of the scope of discrepancies in definitions from this area of research: 
1. Epistemic cognition (King, Kitchener 2004) - the ability to consciously reflect on the limits of cognition, the certainty of cognition, and the criteria of the validity of knowledge; the process that is triggered when solving complex, poorly-structured problems. "While meta-cognition allows one to monitor Level 1 [computing, memorizing, reading, and perceiving] and Level 2 processes [being able to monitor one's progress when engaged in Level 1 tasks], epistemic cognition allows the monitoring of problem types and the evaluation of the proposed solutions" (2004: 38);

2. Epistemological beliefs (Schommer-Aikins 2002) - a form of personal, common-sense, and emotionally charged knowledge that reflects the beliefs, attitudes, and values of an individual which are connected with knowledge and the cognitive process (a complex system of beliefs that operate and develop more or less independently);

3. Epistemic metacognition (Hofer 2004) - beliefs concerning a) the nature of knowledge (including the degree of certainty of knowledge, of its complexity, and of oneself as a "knowing" subject) and b) the anatomy of the cognition process (including the awareness of the sources of one's own knowledge, the criteria of its validity/justification, and the ability to regulate the processes of constructing one's knowledge); and

4. Epistemic thinking (Barzilai, Zohar 2014) - a term that encompasses both epistemic cognition (defined as thinking about the epistemological characteristics of specific information, statements, or sources of knowledge) and epistemic metacognition (i.e., knowledge, skills, and experiences regarding the general nature of knowledge and cognition strategies).

The last term is clearly an attempt to reconcile the variety of definitions, i.e., to include in one broad concept all aspects of epistemological thought which scholars single out in the literature. Underlying this concept is the belief that what distinguishes epistemic thinking from other cognitive processes is not its different structures or patterns, but the subject matter and content of thoughts. It is in this understanding that the term epistemic thinking is used in this article. Without purporting to make judgements on how epistemic knowledge manifests in a child's mind-as "theoryin-action" as Barbara Hofer argued (2004), or rather as loose, common-sense beliefs, as Marlene Schommer-Aikins (2002) claimed, I am interested in the content of this knowledge at a certain stage of development and in the possibilities of supporting its development in the education of children. 


\section{The Development of Epistemic Thinking in Young Children}

As Maria Ledzińska and Maria Czerniawska proclaimed, although there are valid grounds to claim that the basic forms of metacognitive knowledge and epistemic thought are present even in very young children, "they become common only when an individual is able to abstract and consciously reflect on the course of their own cognitive processes" (2011: 357). It was their lack of the capacity for abstract thinking, generalization, and conscious introspection that for many years fueled the disregard for the epistemic potential of young children. The research by Deanna Kuhn (2000), who noted that the sources of epistemological development should be sought in early childhood theories of mind, is considered groundbreaking in this respect. Understanding the so-called false beliefs, i.e., the fact that someone may perceive, experience, and interpret a given situation in a completely different way than we do, is the first step towards a subjective, interpretative concept of knowledge (Białecka-Pikul 2012; Carpendale, Chandler 1996; Wellman 1985). Kuhn based her argumentation on the premise that epistemic thinking should be defined as the declarative dimension of metacognition:

Metacognitive functions can be procedural or declarative. The former refer to awareness and regulation of the course of one's own thinking. The latter engage a broader understanding of thinking and cognition in general and are referred to as epistemic understanding. (Kuhn, Dean 2004: 270)

In this theory, several characteristic levels of development can be distinguished (Kuhn, Dean 2004 272):

The realistic level - when knowledge is perceived as objective, unquestionable, and an exact reflection/copy of reality (i.e., "Everyone knows exactly what I know.");

The absolutist level - when knowledge, although still objective and derived from an external source, is stored in the human mind in the form of cognitive representations/beliefs that may be true or false depending on external circumstances (i.e., "Someone may know or understand events differently from me, but only one of these interpretations is true.");

- The multiplistic (relativistic) level - when knowledge is perceived as a figment of the human mind - uncertain, unable to be evaluated as true or false-because it is constituted by personal opinions, each of which can be valuable and justified, at least in the eyes of a specific subject (i.e., "Others are entitled to their own opinions, which are different from mine."); and

- The evaluative level - knowledge, although generated by the human mind as an interpretation of reality, comprises judgments that can be evaluated and compared 
with each other in terms of their origin or the validity of the arguments and evidence cited in support of them (i.e., "Someone who is right can adequately prove and argue their beliefs.").

The explanation proposed by Kuhn and Dean offers a clear description of the lifelong trajectory of epistemological development and shows how this development is connected with other areas of higher cognitive functions, pointing to their educational importance. However, it does not explain the key driving mechanism of change: Why and under which factors does a child's epistemic thinking change? What can inhibit or even reverse these changes and why? Why don't all adults fully realize their epistemological potential, but stop at relatively early stages of development (King, Kitchener 2004)?

The answers to these questions are provided by studies of educators interested in the educational aspects of epistemic thinking, usually devoted to the understanding of specific mental concepts. The most representative example is the work of Bradford Pillow (2008), who proposed that four characteristic aspects be distinguished in the development of a child's understanding of cognition, though with the caveat that they do not constitute a sequence of separate, disjointed stages of development. They only allow us to describe certain developmental trends and to explain the most important changes in children's thinking. These four aspects of knowledge are as follows (2008: 299):

a) understanding mental states such as desires, intentions, feelings, and beliefs, which appears in early childhood and develops intensely until the breakthrough discovery of false beliefs around the age of 4;

b) awareness of the existence of various cognitive processes, i.e., knowledge about the mental activities which generate, select, transform, manipulate, or operate the content of mental states. The main mental processes include attention, remembering, forgetting, inferring, guessing, and problem-solving. In a basic form, awareness of the existence of these processes and their functions and characteristics first occurs in the transition period between early and middle childhood (5-7 years of age) and gradually increases;

c) organizational knowledge, understood as an awareness of the relationship (similarities and differences) between different cognitive processes; such knowledge first starts to grow in late childhood (9-10 years of age); and

d) epistemological thought, which refers to a reflection on the nature of knowledge in general and its relations with reality; it appears in early adolescence (13-14 years of age) and develops at an individual pace throughout adult life.

The basic understanding of mental states, described in the literature as "naïve theories of mind," appears in early childhood-even prior to the age of 3, children learn to recognize desires, emotions, and intentions (Białecka-Pikul 2012; Wellman 1985). 
Before they turn 4, they also acquire the ability to understand human beliefs as representations of reality, which may be adequate or consistent with facts, or inadequate or false. These early concepts also involve recognizing personal differences in people's mental states and their sources of perception. However, research shows that young children do not fully appreciate the way and the extent to which the cognitive activity of the human mind can influence a person's mental states. A quantum leap in children's perception of knowledge and mental processes takes place only around the age of 6 or 7 (Pillow 2008: 298). Research shows that before the age of 6 , children treat knowledge as an objective copy of external reality and do not allow for the possibility of multiple, diverse, subjective interpretations of the same input data provided by the senses.

An awareness of various forms of cognitive activity means the awareness of both consciously initiated and automatically triggered processes, and includes the recognition of the functions and characteristics of these processes, their typical outcomes, and their conditions of occurrence, i.e., the stimuli that activate them. Pillow says that adults can usually name many different forms of mental activity, but that their metaepistemic knowledge remains rather limited — superficial and vague. It is rare for the average person to be able to explain the mechanisms of information processing that occurs during a mental process, e.g., people generally know that attention is selective, but usually cannot explain the mechanism of this selectivity. Instead of reflecting on a model of selective attention, they know that a person watching TV in a crowded room with several conversations going on in the background will probably be able to recreate the content of the program they watched, but not the content of the ongoing conversations. They can also attribute this outcome to the process of focusing on important information or blocking useless information. They may also judge it as difficult, requiring a lot of effort, and prone to distraction-depending on the individual's abilities, knowledge, and beliefs about attention. In other words, the knowledge of most average adults about specific cognitive processes is casual and contextual, firmly embedded in the realities of everyday life, involving an awareness of the likely or desired results of a mental activity rather than a precise explanation of its mechanisms (Pillow 2008: 300).

In a child, the knowledge of the mind's cognitive activity begins between the ages of 5 and 7 , possibly influenced by educational experiences. While it is true that small children (3-4 years old) may already use simple terminology to name some cognitive processes ("I know," "I think," etc.), they do not appreciate the role these processes play in constructing the cognitive representation of reality. It is only during their primaryschool education and within the requirements set by the school that their awareness of the diverse and complex activity of the human mind increases considerably. Pillow says that "during early childhood, knowledge of mental functioning is organized in 
terms of relations among beliefs, desires, action, and perception, and during middle childhood, this simple belief-desire reasoning begins to be elaborated into a conception of the mind as an active information processor, in which children understand that processes such as reasoning, remembering, learning, and imagining contribute to the formation of belief," and mediate it, significantly influencing the final shape of human knowledge (2008: 305). When children's understanding of the existence of various cognitive processes becomes sufficiently deep and detailed (including an awareness of the typical features inherent in each mental activity), they develop the ability to consciously reflect on human cognitive functioning and start to organize their knowledge in terms of the similarities and differences between the characteristics and functions of cognitive processes.

In this context, Henry Wellman's research on children's understanding of the concept of mind and brain (1985) seems particularly interesting. In one of the studies, Wellman compared adult and childhood perceptions of the role of the brain in human activities. The participants of the study were asked if they needed the brain to perform various types of activities: mental tasks (memory, knowledge, and dreams); sensory activities (looking and tasting); school tasks (learning, counting, etc.); other observable behaviors, both involuntary (coughing) and conscious or deliberate (jumping on one leg); and various types of feelings, from physiological reactions (feeling sleepy or hungry), through simple emotions (sadness or joy), to complex cognitive feelings (curiosity). Adults recognized the role of the brain in all these forms of human activity. The youngest children's answers differed significantly from the adults' responses. They perceived the brain in terms similar as the mind: as a common habitat for various conscious cognitive processes, such as thinking, dreaming, learning, etc. For children, involuntary, peripheral, and unconscious (passive) behavior does not fit into this model. According to Wellman (1985: 190), this proves the internal inconsistency of early childhood concepts; the brain seems to be conceptualized on par with other organs of the body, as autonomous and separate, with its own designated area of activity: the eyes see, the legs walk, the ears hear, and the brain thinks. Consequently, young children believe that the brain can be "turned off" and one can stop thinking (Flavell, Green, Flavell 1995: 79). It is only at school age that this view of the mind becomes more physiological or embodied, as children begin to gradually notice the differences between the brain - which is also involved in automatic processes (involuntary, inadvertent, and uncontrollable) —and the mind as the center of exclusively intentional, consciously activated cognitive activities. As they start discerning these differences, children progress towards an awareness of the functional interdependence between the organs: they now perceive the brain as controlling other organs of the body, but at the same time as aided by the information flowing from them. This way, children develop an understanding of the "stream of consciousness," so they realize 
that the brain cannot be switched off or stopped - that it always works, even when we are seemingly doing nothing, for example, when we are sleeping.

Research shows that as children's knowledge transforms into an increasingly ordered, organized, and conscious form, a new, more abstract concept of mental phenomena begins to emerge (Pillow 2008: 307).

First, children begin to realize that mental processes are not singular, fleeting, or isolated events, but on the contrary, that thinking is a complex and multidimensional sequence of systematic, organized, and purposeful activities undertaken in the course of planning, problem-solving, and decision-making. This is a very important metacognitive milestone, as the child's conception of the mind is changing: "viewing thought in terms of deliberately related cognitive acts implies knowledge of the mind as an organized processor of information" (Pillow 2008: 32);

- Later, children also begin to notice that some cognitive processes are subjective interpretations based on incomplete or ambiguous premises (input data), which may lead to cognitively uncertain results, or to different, subjective points of view (perception perspectives). According to Paula J. Schwanenflugel, children's subjective experiences of the uncertainty or even ambiguity of the outcomes of cognition initiates and supports the process of building a constructive theory of mind (as cited in: Pillow 2008: 32), thus instigating a number of significant changes in children's understanding of cognitive processes.

Many researchers emphasize that it is the perception of subjectivity as an inherent feature of knowledge and cognition that opens the way to the development of epistemological reflection (Alexander, Schwanenflugel 1996; Białecka-Pikul 2012; Kuhn 2000). True, the understanding of subjectivity in its most basic form appears even in early childhood, but then it is still very superficial and limited. Children who are 4 or 5 years old appreciate that a person may have false beliefs, but they attribute this only to objective external circumstances. As a result, they find it easier to understand differences in the perceptual experience of reality that arises from the different external circumstances of the participants/witnesses of an event (situational viewpoints) than individual perspectives of people with different psychological characteristics, such as character traits, attitudes, beliefs, emotions, etc. (subjective viewpoints) (Higgins, as cited in: Pillow 2008: 15). Beginning around age 7, children begin to recognize that internal mental processes can also contribute to the formation of subjective interpretations of reality. However, initially this understanding is specific, embedded in a situational context: children admit that ambiguous information may be misinterpreted by a naïve, manipulated, or biased observer (Pillow 2008: 15). Only later, as adolescents, will they gain the full awareness that human knowledge and beliefs are inherently subjective because they are constructed by the mind in the course of complex psychological processes that leave a strong mark on the final shape of human 
cognition. As Kuhn concludes, the driving force of epistemological development lies in the ability to coordinate and reconcile the subjective and objective dimensions of knowledge, maintaining a balance between them, depending on the circumstances, task, or field of learning (Kuhn, Dean 2004: 271).

\section{Children's Concepts of Knowledge and Learning in Light of Empirical Research}

The study presented below was conducted as part of an MA seminar on developing children's motivation to learn. The article uses the research material collected by Anna Gawrych (2017) according to Piaget's clinical interview. At the outset, the children were asked to make a drawing: "I would like to ask you for help-I'm writing a book for children about knowledge and learning, but I have no idea for a cover for this book. Think about the difference between these two concepts: knowledge and learning. What should the cover show so that everyone notices the difference immediately? Try to draw such a cover." After they finished drawing a picture, the children were asked to explain: "What does your drawing show? How would you explain to a friend the way knowledge differs from learning?"

Thirty children participated in the research, including 15 pupils from grades 2 and 3. The vast majority of children came from two-parent families (96.7\%), with a high or medium sociocultural status (30\% and $46.7 \%$, respectively). The results of the semantic analysis of the collected verbal and visual materials are presented below.

According to the children, the most important difference between the two concepts is that learning is a process (acting or doing something) and knowledge is a state, a resource. Interestingly, however, not all the children saw a cause-effect relationship between learning and knowledge: to know something, you must learn it beforehand, understand it, and remember it: "Once we learn something, we know it" (Zbyszek, 3rd grade). Some explanations were based on a temporal relationship: "Learning comes first, then knowledge" (Mateusz, 2nd grade).

The respondents explained the essence of learning as gaining knowledge and new experiences (16 children) or acquiring wisdom ( 2 children). Their explanations were firmly rooted in the context of specific school experiences, which is especially conspicuous in the drawings of the classroom, a blackboard, a teacher explaining a task,

\footnotetext{
Due to the volume of the material collected, only the first two of eight questions planned in the interview were used in this article. The full structure of the interview is described in the thesis written by A. Gawrych (2017) under my supervision. The student agreed to use the empirical material that she collected to prepare this publication.
} 
etc. (Fig. 1). Learning is seen in terms of an obligation, not always a pleasant one, imposed by adults: "Learning is when we go to school" (Marta, 2nd grade); "It's gaining knowledge in class" (Marta, 3rd grade); "We learn when the teacher is explaining things in the classroom" (Natalka, 3rd grade); "We write and solve different problems" (Zbyszek, 3rd grade); "Learning is when the teacher assigns homework-what we learned in class" (Maks, 2nd grade); "We learn when we read books and when the teacher praises me" (Natalia, 3rd grade); "Learning is solving many tasks" (Paulina, 3rd grade); "Learning is repetition, assigning homework, and answering the teacher's questions in class" (Mateusz, 2nd grade); "It's a kind of an obligation to have a good job in the future" (Kinga, 3rd grade).

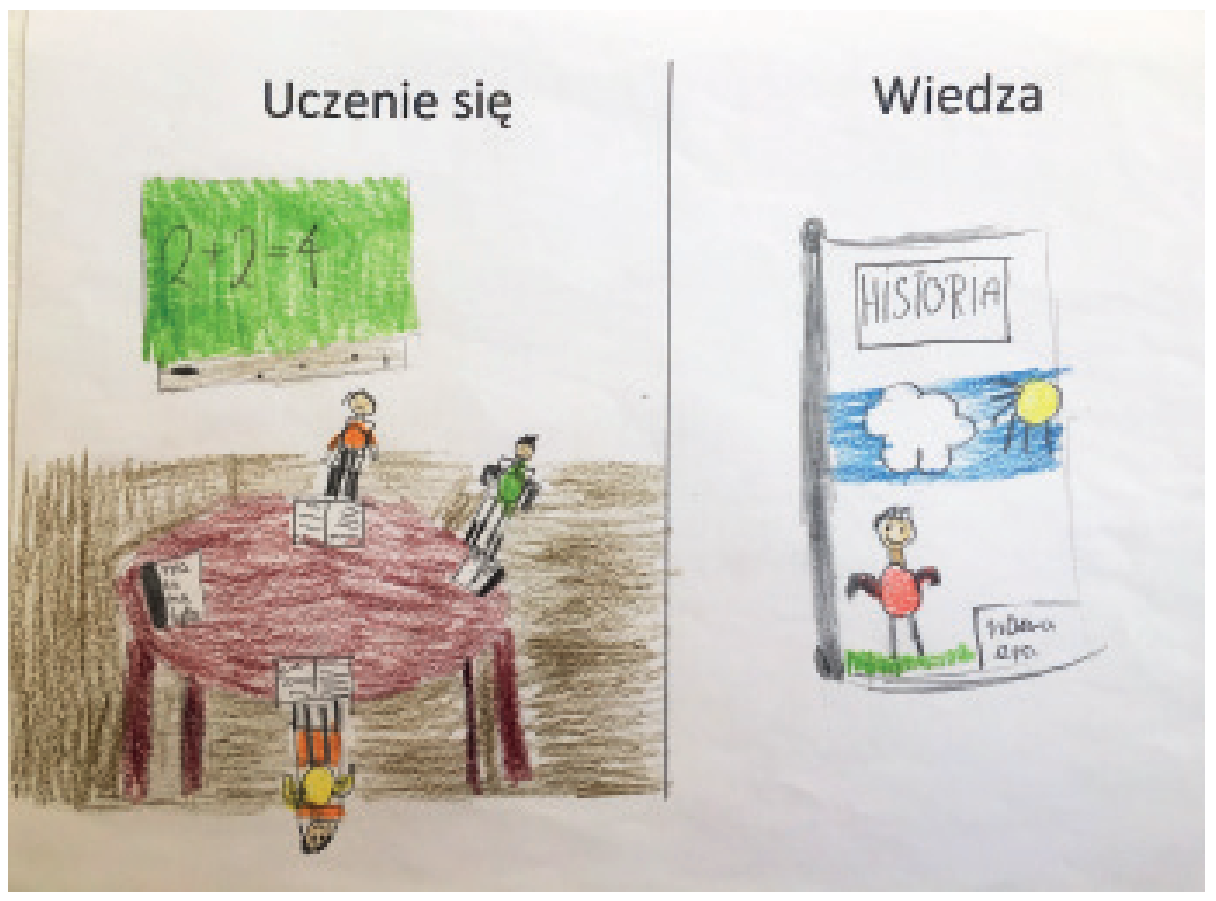

Fig. 1. "Children learn at school, and knowledge is wisdom, but wisdom from books" (Paulina, 3rd grade)

Source: Gawrych 2017: 57

Children associated learning with the outside world, play, and extracurricular activities much less frequently (Fig. 2): "We learn to play ball" (Wojtek, 3rd grade); "We learn when we visit a castle during a trip" (Maks, 2nd grade); "Learning is gaining knowledge on a trip to the mountains" (Paulina, 2nd grade); or "Because when 
I learn, it's like I was climbing to the top of a mountain, and then I know things like in an encyclopedia" (Adaś, 2nd grade). The analysis of children's statements reveals two key characteristics attributed to learning:

a) External source - learning is organized, guided, and assessed by adults. The children themselves do not perceive their own influence on the course of learning: you have to do what the teacher tells you to do

b) Repetition or multiplicity - to learn something, you have to repeat an activity many times, to practice and revise it. According to Ingrid Pramling (1986), grasping this truth marks the beginning of the development of childhood concepts of learning and, in the developmental sense, is a step ahead of the knowledge of learning as a mental activity.

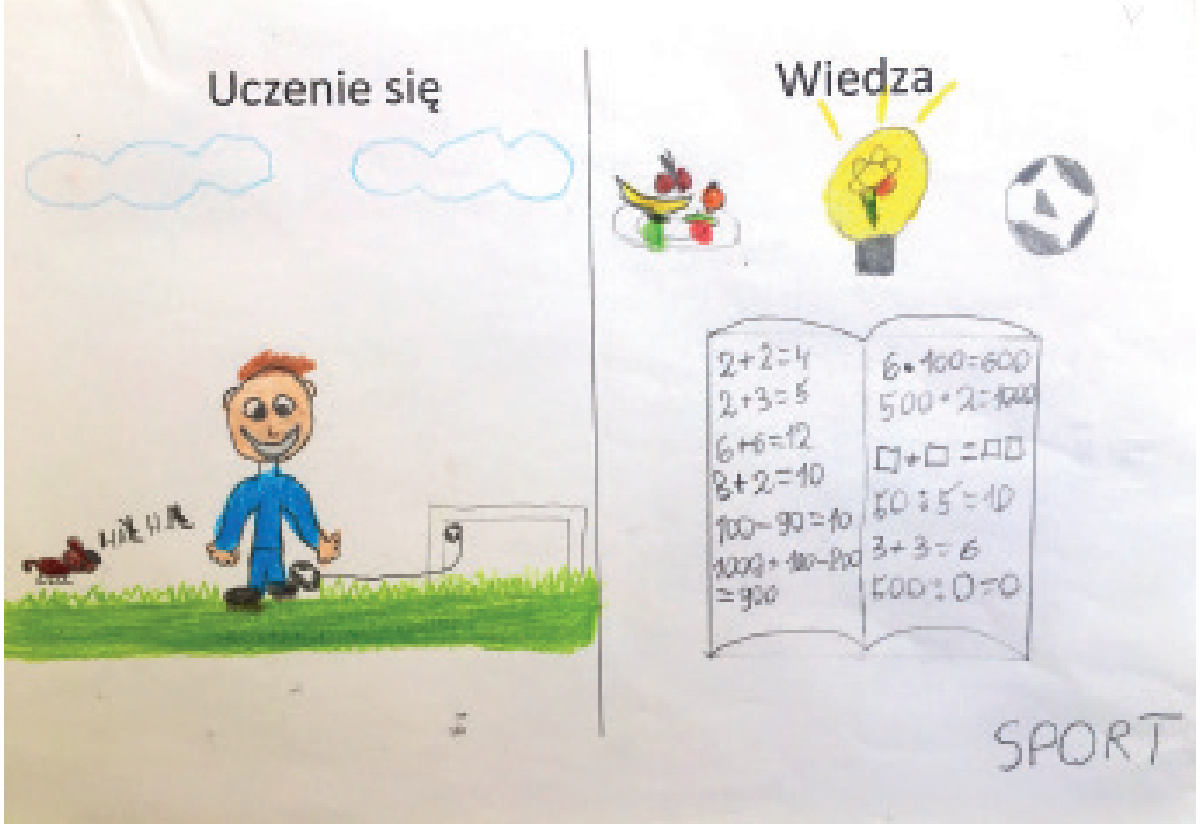

Fig. 2. "The boy is playing soccer and is happy because he is learning something new.

Knowledge is what I can do and what I know that I didn't know before." (Michał, 2nd grade)

This does not mean, however, that children are unaware of the involvement of the mind in the learning process. The statements of the respondents included mental activities such as thinking ( 24 children), listening ( 3 children), remembering ( 6 children), understanding ( 2 children), and focus ( 4 children). Here are some examples of such statements: "We listen and then all the thoughts enter our mind and we 
remember" (Adaś, 2nd grade); "We remember information and think" (Staś, 2nd grade); "The head absorbs more knowledge" (Mateusz, 2nd grade); "We expand our gray matter" (Staś, 3rd grade); "Learning is thinking, we feel warm and our thinking develops" (Wojtek, 3rd grade); "We learn to keep something in our head, we gain wisdom" (Amelia, 2nd grade).

Unlike the idea of learning, the more abstract concept of knowledge turned out to be much more difficult to define: the children had a clear problem finding sufficiently precise words and creating a generalized definition. Their explanations can be placed on a continuum, ranging between the perception of knowledge as an objective and coming from sources external to oneself (knowledge comes from books or from the teacher) and an understanding of knowledge as an internal, subjective category (knowledge is the content of the human mind, everything we know; Fig. 4). Such a variety of answers reflects the developmental trends which are well-described in the literature and proves that children's concepts of knowledge are undergoing intensive evolution and crystallization (Table 1).

Table 1. Children's Concepts of Knowledge

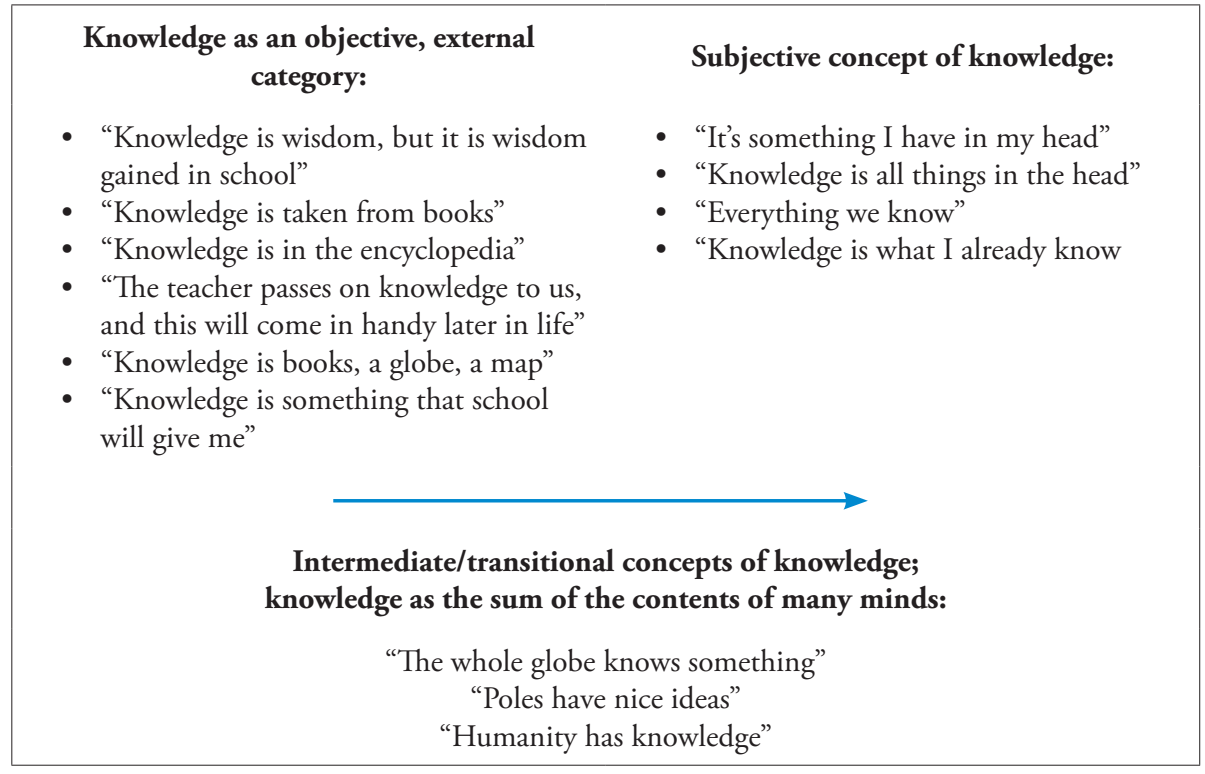

From a developmental point of view, it is more advanced to see knowledge as the content of the human mind. The surveyed children identified three basic aspects of knowledge:

a) The novelty of the information gained: "Knowledge is what I already know and can do that I didn't know before (Michał, 2nd grade); "When we gain new 
experiences that are useful in life" (Kamil, 2nd grade); "Knowledge is learning something new that I didn't know before" (Julian, 3rd grade)

b) The need to intellectually "domesticate" knowledge - "Knowledge is thinking" (Wojtek, 3rd grade); "We know because we have already learned by heart" (Adaś, 2nd grade); "We know something and we understand what it is" (Kinga, 3rd grade)

c) The practical usefulness of knowledge - "Knowledge is wisdom" (11 children); "an open mind" (Staś, 3rd grade); the ability to create new, interesting ideas ( 6 children), often represented in the drawings by the symbol of a light bulb (Figs. 2 and 3).

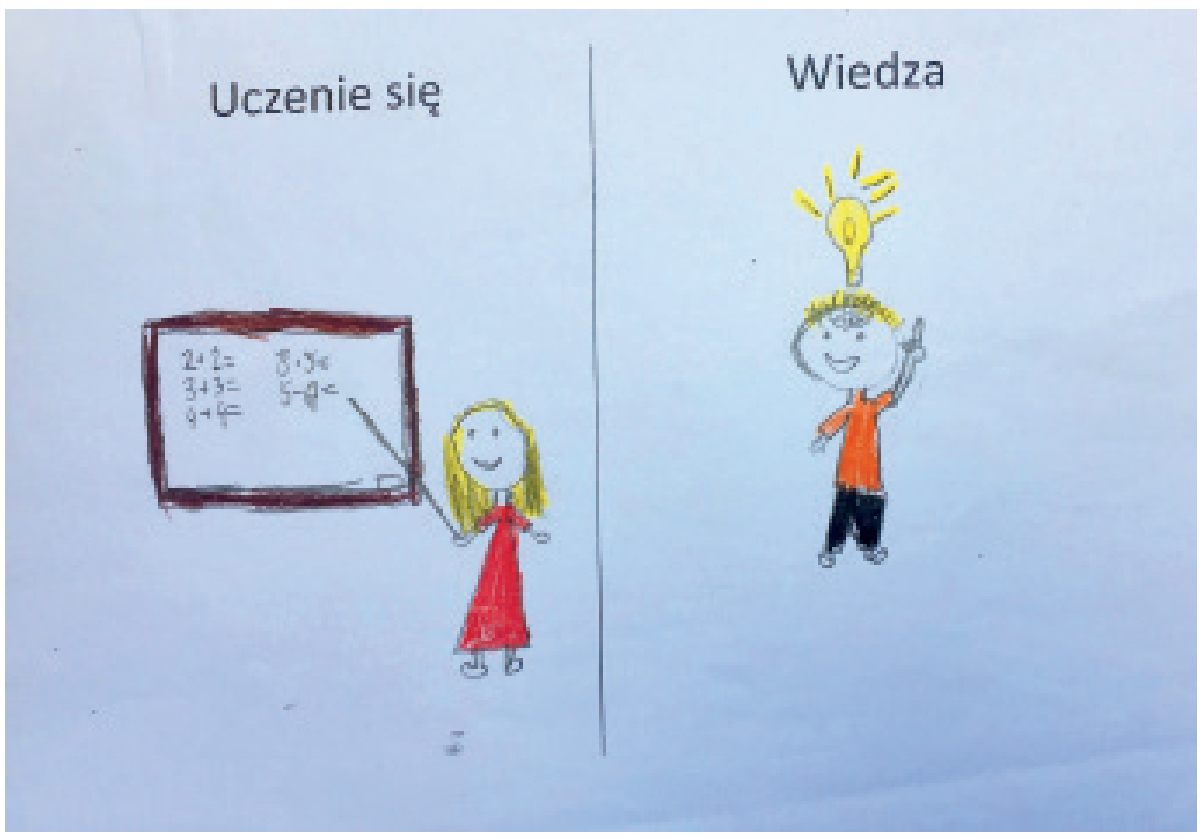

Fig. 3. "A girl who is explaining different tasks to us and a boy who has different ideas. Learning is studying and knowledge is wisdom. We learn to be someone very important one day, then we can achieve something in the future." (Natalia, 2nd grade)

While identifying knowledge with wisdom or ingenuity may seem too broad, it is likely the result of perceiving knowledge as coming from an authority. On the one hand, knowledge is the content of the human mind, but on the other hand, not everyone has enough knowledge to be taken for a wise person (the more knowledge one has, the wiser one is). The apparent contradiction in this childhood belief confirms the thesis expressed by many researchers that epistemological knowledge, at least in 
the early stages of development, does not form an internally coherent theory, but rather resembles a set of loosely related casual beliefs, which are emotionally charged, often resistant to logic, and changeable, because they are built on the basis of current experience (Schommer-Aikins 2002).

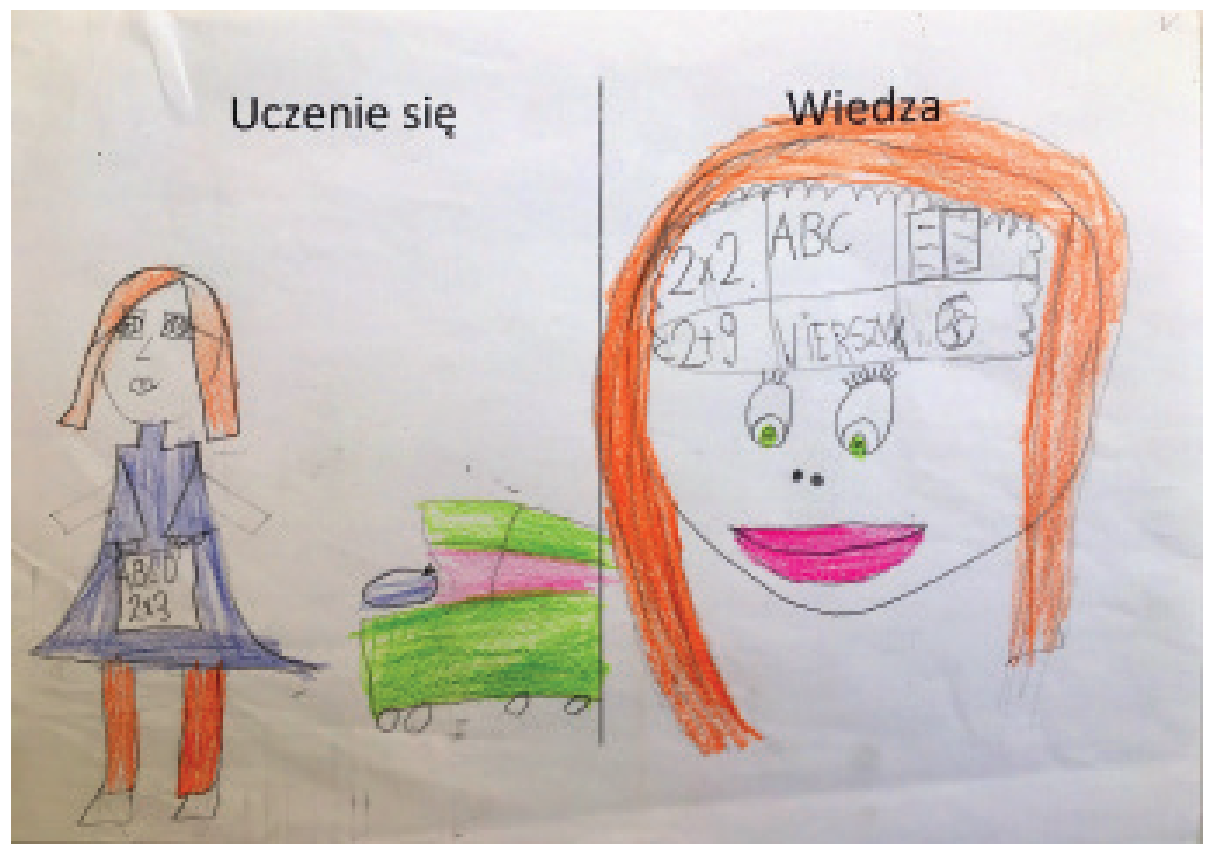

Fig. 4. "The girl learns by thinking in the brain. This knowledge is already in her head." (Aleksandra, 2nd grade)

\section{Conclusion}

This empirical study does not claim the right to formulate generalizations. The purpose was rather to make readers aware that the epistemological thinking of younger school-aged children exhibits qualitatively important changes, new areas of sensitivity, and the reflection that the teacher should notice and support. Although at this age_-according to the development trajectory described by Kuhn and Dean (2004) children's reasoning is still deeply rooted in the absolutist perception of knowledge, they begin to notice the role that various mental processes (thinking, attention, memory, understanding) play in constructing knowledge. Under the influence of school, they develop the need to understand these processes and to subject them to conscious control. A reflection on the structure and course of these cognitive processes emerges 
spontaneously, as does the "organizational knowledge" (Pillow 2008), i.e., the awareness that these mental activities do not occur in isolation, but form a complex chain of interactions. The child needs the help of a teacher to understand the characteristics and the relationships between the mental operations that constitute thinking and learning.

This research also shows that, in children's consciousness, the understanding of the learning process is bound to the concept of knowledge (Fig. 5): they constantly interact, influence, and shape each other. As Pramling states (1986: 36-37), the development of children's concepts of learning consists of three basic stages: a) learning in order to do something, b) learning to know something, and c) learning to understand the world. The vast majority of the study participants are in the second stage of development: the children are clearly aware of their own active role in the learning process, they know that in order to master a skill, it is necessary to repeat it many times, to practice it, and to solve many tasks in order to become proficient. However, they identify this building of knowledge mainly with quantitative processes: remembering or gathering data, facts, and information in the mind, which is evaluable in terms of "true or false" and comes from the outside (from books or from the teacher). On the one hand, the use of such an objectivist conception of knowledge is a natural stage in human epistemic development (Białecka-Pikul 2012; Kuhn, Dean 2004; Wellman 1985). On the other hand, the beginning of school education requires the formative intervention of the environment-an intervention that will help children to move from perceiving knowledge in purely objective terms to understanding it as a subjective, personal interpretation of information, which requires them to think critically, weigh arguments, and recognize contextual factors. Only perceiving knowledge as being refutable and requiring justification and argumentation activates such areas of epistemological reflection as critical thinking, investigating the sources of one's own knowledge, realizing the criteria of its validity, the strength of arguments, etc. Encouraging such a reflection is an important task of early education. The statements of some of the respondents indicate that they are ready for such reflection, e.g., "Knowledge means an open mind, so as not to be such a person who doesn't have a goal and who doesn't learn from mistakes" (1 person). 
Fig. 5. Relationships between children concepts of knowledge and learning in light of the conducted research

\begin{tabular}{|c|c|}
\hline Concepts of learning & Concepts of knowledge \\
\hline $\begin{array}{l}\text { 1. Learning in order to do } \\
\text { learning as action, being involved and gaining } \\
\text { experience }\end{array}$ & $\begin{array}{l}\text { No concept of knowledge } \\
\text { the pre-reflection stage - skills are perceived } \\
\text { as the result of thinking "I figured out how } \\
\text { to do it" }\end{array}$ \\
\hline $\begin{array}{l}\text { 2. Learning in order to know } \\
\text { learning is gaining knowledge about the } \\
\text { world }\end{array}$ & $\begin{array}{c}\text { An objective concept of knowledge } \\
\text { knowledge as the content of the human mind } \\
\text { but viewed as the sum of objective, verifiable } \\
\text { information }\end{array}$ \\
\hline $\begin{array}{l}\text { 3. Learning in order understand } \\
\text { learning is understanding the meaning of } \\
\text { things and events in the world and their } \\
\text { mutual relationships }\end{array}$ & $\begin{array}{l}\text { Transition to a subjective } \\
\text { concept of knowledge } \\
\text { understanding based on the question "why" } \\
\text { permits various explanations and requires } \\
\text { justification and argumentation }\end{array}$ \\
\hline \multicolumn{2}{|c|}{$\begin{array}{l}\text { Epistemological reflection } \\
\text { on the sources and criteria for the validity of knowledge and } \\
\text { one's own role in building and organizing it }\end{array}$} \\
\hline
\end{tabular}

"When we know something it means that we understand it" (2 people). However, activating such thinking is up to the teacher and the epistemological atmosphere they build in the classroom - the questions they consistently and systematically ask: How do we know what we know? Why do we think that? What confirms our thinking? How do we explain this to someone who disagrees with us?

To sum up, numerous studies indicate that epistemic thinking is an important factor that shapes the effectiveness of education at an earlier school age (Bendixen, Feucht 2010; Kuhn, Weinstock 2002). The better children understand the mechanisms of the learning process, the faster they are able to take conscious control of it. The better they understand what knowledge is and how it can be organized in the human mind, the more aware they become of their own role in constructing this knowledge (Pramling 1986). However, none of these areas of consciousness develop automatically-the educational setting can play both a stimulating and impeding role in this process. There are empirical grounds to believe that this type of didactic intervention may be effective and beneficial even at the stage of early education (Hofer, Bendixen 2012: 236). However, this is a relatively new research area that requires in-depth exploration. 


\section{Bibliography}

Alexander J.M., Schwanenflugel P.J. (1996). Development of metacognitive concepts about thinking in gifted and non-gifted children: Recent research, "Learning \& Individual Differences," vol. 8, no. 4 pp. 305-325.

Barzilai S., Zohar A. (2014). Reconsidering personal epistemology as metacognition: A multifaceted approach to the analysis of epistemic thinking, "Education Psychologist," vol. 49 (1), pp. 13-35.

Bendixen L.D., Feucht F.C. (eds.) (2010). Personal epistemology in the classroom. Theory, research, and implication for practice, New York: Cambridge University Press.

Bendixen L.D., Rule D.C. (2004). An integrative approach to personal epistemology: A guiding model, "Educational Psychologist," vol. 39 (1), pp. 69-80.

Białecka-Pikul M. (2012). Narodziny i rozwój refleksji nad myśleniem [The birth and development of reflection on thinking], Krakow: UJ.

Briell J., Elen J., Verschaffen L., Clarebout G. (2011). Personal epistemology: Nomenclature, conceptualizations, and measurements, [in:] J. Elen, E. Stahl, R. Bromme, G. Clarebout (eds.), Links between beliefs and cognitive flexibility: Lessons learned, Springer Science+Business Media, pp. 7-36.

Carpendale J.I., Chandler M.J. (1996). On the distinction between false belief understanding and subscribing to an interpretive theory of mind, "Child Development," vol. 67, pp. 1686-1706.

Feucht F.C. (2010). Epistemic climate in elementary classrooms, [in:] L.D. Bendixen, F.C. Feucht (eds.), Personal epistemology in the classroom: Theory, research, and implications for practice, Cambridge: Cambridge University Press, pp. 55-93.

Flavell J.H. (1979). Metacognition and cognitive monitoring: A new area of cognitive-developmental inquiry, "American Psychologist," vol. 34 (10), pp. 906-911.

Flavell J.H., Green F.L., Flavell E.R. (1995). Young children's knowledge about thinking, "Monographs of the Society for Research in Child Development," series no. 243, vol. 60 , no. 1 .

Gawrych A. (2017). Koncepcja uczenia się w wypowiedziach dzieci w mtodszym wieku szkolnym [The concept of learning in the statements of younger school children] [Unpublished thesis, written under the supervision of Dr. Dorota Zdybel for the University of Social Sciences in Łódź].

Hofer B. (2004). Epistemological understanding as a metacognitive process: Thinking aloud during online searching, "Educational Research," vol. 39 (1), pp. 43-55.

Hofer B.K., Bendixen L.D. (2012). Personal epistemology: Theory, research, and future directions, [in:] APA educational psychology handbook. DOI: 10.1037/13273-009. https:// www.researchgate.net/publication/284893012_Personal_epistemology_Theory_research_and_future_directions

Hoskins, B., Fredriksson, U. (2008). Learning to learn: What is it and can it be measured? "JRC Scientific and Technical Reports," Luxemburg: Office for Official Publications of the European Communities. 
Kanevsky L., Geake J. (2004). Inside the zone of proximal development: Validating a multifactor model of learning potential with gifted students and their peers, "Journal for the Education of the Gifted," vol. 28 (2), pp. 182-217.

King P.M., Kitchener K.S. (2004). Reflective judgment: Theory and research on the development of epistemic assumptions through adulthood, "Educational Psychologist," vol. 39 (1), pp. 5-18.

Key competences in the process of lifelong learning. European Reference Framework. EU Council Recommendations of 22 May 2018 on Key Competences for Lifelong Learning. (2018/C 189/01). https://eur-lex.europa.eu/legal-content/PL/TXT/PDF/?uri=CELE $\mathrm{X}: 32018 \mathrm{H} 0604(01) \&$ from=EN

Kuhn D. (2000). Theory of mind, metacognition, and reasoning: A life-span perspective, [in:] P. Mitchell, K.J. Riggs (eds.), Children's reasoning and the mind, New York: Psychology Press, pp. 301-326.

Kuhn D., Dean D. Jr. (2004). Metacognition: A bridge between cognitive psychology and educational practice, "Theory Into Practice," vol. 43 (4), pp. 268-273. DOI: 10.1207/ s15430421 tip4304_4

Kuhn D., Weinstock M. (2002). What is epistemological thinking and why does it matter?, [in:] B.K. Hofer, P.R. Pintrich (eds.), Personal epistemology: The psychology of beliefs about knowledge and knowing, New York: Routledge, pp. 121-144.

Ledzińska M., Czerniawska M. (2011). Prawidtowości rozwoju sfery metapoznawczej $w$ teorii i praktyce nauczania [Patterns of the development of the metacognitive function in teaching theory and practice], [in:] J. Trempała (ed.), Prawidtowości rozwoju cztowieka [Patterns of human development], Warsaw: PWN, pp. 353-363.

Pillow B.H. (2008). Development of children's understanding of cognitive activities, "The Journal of Genetic Psychology," vol. 169 (4), pp. 297-321.

Pramling I. (1986). The origin of the child's idea of learning through practice, "European Journal of Psychology of Education," vol. 1 (3), pp. 31-46.

Schommer-Aikins M. (2002). An evolving theoretical framework for epistemological belief system, [in:] B.K. Hofer, P.R. Pintrich (eds.), Personal epistemology: The psychology of beliefs about knowledge and knowing, Mahwah, NJ-London: LEA Publishers, pp. 103-118.

Wellman H.M. (1985). The child's theory of mind: The development of conceptions of cognition, [in:] S.R. Yussen (ed.), The growth of reflection in children, Orlando, FL: Academic Press.

\section{ADDRESS FOR CORRESPONDENCE}

Dorota Zdybel

Jesuit University Ignatianum in Krakow e-mail: dorota.zdybel@ignatianum.edu.pl 